\title{
Free-radical degradation of high-molar-mass hyaluronan induced by ascorbate plus cupric ions: Testing of stobadine and its two derivatives in function as antioxidants
}

\author{
Lubica Surovcikova-Machova ${ }^{1}$, Katarina Valachova ${ }^{1}$, Maria Banasova ${ }^{1}$, Vladimir Snirc ${ }^{1}$, \\ Elena Priesolova ${ }^{2}$, Milan Nagy ${ }^{2}$, Ivo Juranek ${ }^{1}$ and Ladislav Soltes ${ }^{1}$ \\ ${ }^{1}$ Institute of Experimental Pharmacology and Toxicology, Slovak Academy of Sciences, 84104 Bratislava, Slovak Republic \\ ${ }^{2}$ Faculty of Pharmacy, Comenius University, 83232 Bratislava, Slovak Republic
}

The authors dedicate this paper to the relatives of our co-author Dr. Vladimír Šnirc who died tragically on May 30, 2011.

\begin{abstract}
Stobadine.2HCl and its two hydrophilic derivatives SM1dM9dM10.2HCl and SME1iProC2 $\cdot \mathrm{HCl}$ were tested in the function of antioxidants on hyaluronan (HA) degradation induced by the Weissberger oxidative system [ascorbate plus $\mathrm{Cu}(\mathrm{II})$ ]. As a primary method, rotational viscometry was applied, where the substance tested was added before or $1 \mathrm{~h}$ after the initiation of HA degradation. The most effective scavengers of ${ }^{\bullet} \mathrm{OH}$ and peroxy-type radicals were recorded to be stobadine. $2 \mathrm{HCl}$ and SME1i-ProC2 $\cdot \mathrm{HCl}$, respectively. The most effective scavenger, determined by applying the ABTS assay, was stobadine.2HCl.
\end{abstract}

Key words: ABTS assay - Glycosaminoglycans - Hexahydropyridoindole derivatives - Rotational viscometry - Weissberger oxidative system

Abbreviations: ABTS, 2,2' -azinobis-(3-ethylbenzothiazoline-6-sulfonic acid; GAG, glycosaminoglycan; HA, hyaluronan; HHPI, hexahydropyridoindole; SF, synovial fluid; THPI, tetrahydropyridoindole.

\section{Introduction}

Hyaluronan (HA, Figure 1) is a glycosaminoglycan (GAG) found especially in extracellular matrix of vertebrate organisms. It is distinct from other GAGs in that it is a non-sulfated, non-protein bound and non-branching polymer of repeating dissacharides of d-glucuronic acid and $N$-acetyl-d-glucosamine linked via alternating $B-1,4$ and $ß-1,3$ glycosidic bonds (Stern 2003; Puré and Assoian 2009). HA is widely distributed in vertebrate connective tissues, particularly in umbilical cord, synovial fluid (SF), vitreous humor, dermis, cartilage, and intervertebral disc (Kongtawelert and Ghosh 1989). In SF, high-molar-mass $\mathrm{HA}$ is in the physiological concentration $2-3 \mathrm{mg} / \mathrm{ml}$. It

Correspondence to: Katarina Valachova, Institute of Experimental Pharmacology and Toxicology, Slovak Academy of Sciences, Dubravska cesta 9, 84104 Bratislava, Slovak Republic

E-mail: katarina.valachova@savba.sk provides there the necessary lubrication for the joint and serves as a shock absorber, reducing friction of the moving bones and diminishing wear of the joint (Kogan et al. 2007; Šoltés et al. 2007a).

In normal tissues, molar-mass of HA can reach several million Daltons (Puré and Assoian 2009). By the length of its chain, large HA polymer has spacefilling function and is anti-angiogenic and immunosuppressive. Intermediatesize polymer, either synthesized de novo or generated by enzymatic degradation, comprising 25-50 disaccharides, is pro-inflammatory, immunostimulatory, and highly angiogenic, and it appears to function as endogenous stress signal (Stern et al. 2007).

The turnover of HA is extremely rapid. It is estimated that of $15 \mathrm{~g}$ of $\mathrm{HA}$ in a $70 \mathrm{~kg}$ human body, $5 \mathrm{~g}$ turn over daily. The half-life of HA in the circulation is from 2 to $5 \mathrm{~min}$. In the epidermis it is 1 to 2 days, in SF several hours, and in cartilage approximately 1 to 3 weeks (Šoltés et al. 2005; Stern et al. 2007). 


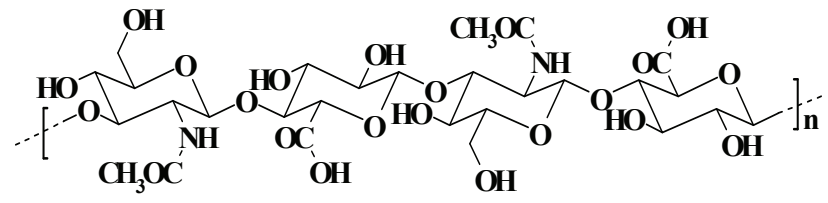

Figure 1. Hyaluronan - acid form.

Under inflammatory conditions of arthritic diseases, such as osteoarthritis or rheumatoid arthritis, high-molar-mass HA is degraded by reactive oxygen species, which reduce the viscosity of SF and impair its lubricant and shock absorbing properties, leading to dysfunction of the joint and severe pain (Yamazaki et al. 2003; Kogan et al. 2007).

The pyridoindoles, 2,3,4,5-tetrahydro- (THPI) and 2,3,4,4a,5,9b-hexahydro- $1 H$-pyrido[4,3b]indole (HHPI), rank among substances used in the treatment of cardiovascular and neuronal disorders. Some of these drugs (Figure 2) are used in clinical practice such as antihistaminics, e.g. mebhydroline (Waitzinger et al. 1995), antipsychotics, e.g. a racemic substance - carbidine (Yakhontov and Glushkov 1983), antiemetics, e.g. alosterone (Schoenfeld 2005).

At present, THPI and HHPI substances are administered in treating Alzheimer's, Parkinson's, and Huntington's diseases (Ivashchenko et al. 2010), sclerosis multiplex, sudden celebral and vascular episodes, states of ischemia, diabetes mellitus, and chronic inflammation (Hung 2008). To date, the THPI derivatives are the topic of more than two thousands of clinical and experimental studies and about 500 patents devoted to these groups of substances have been pended (Ivachtchenko et al. 2010).

In the Institute of Experimental Pharmacology and Toxicology of the Slovak Academy of Sciences the original substances from the group of HHPI derivatives have been developed for more than two decades. One of them, stobadine (Fig. 3) - an optical enantiomer of carbidine (Figures 2), is a cardioprotective and antihypoxic agent (Kittová et al. 1985), which exerted benefical effects in the 1st and 2nd stage of clinical tests (Šoltés et al. 2000). The antioxidative effect of stobadine $2 \mathrm{HCl}$ is related to the presence of the indoline - $\mathrm{NH}$ - group that directly participates in the reaction with an unpaired electron of a reactive radical (Staško et al. 1990; Steenken et al. 1992; Kagan et al. 1993; Račková et al. 2002). Protective effects of stobadine $\cdot 2 \mathrm{HCl}$ on ascorbate plus $\mathrm{Cu}(\mathrm{II})$-induced HA degradation were published by Rapta et al. (2010), whereas this substance was shown to be a remarkable scavenger of ${ }^{\circ} \mathrm{OH}$ and peroxy-type radicals in a dose-independent manner.

Stobadine derivatives were demonstrated to be effective antioxidants, particularly the hydrophilic derivates SMe1EC2 $\cdot \mathrm{HCl}$ and SM1M3EC2 $\cdot \mathrm{HCl}$, investigated in the function of ${ }^{\bullet} \mathrm{OH}$ and peroxy-type radical scavengers. The results of rotational viscometry showed, however, that these derivatives had less protective effects against free radicalmediated HA degradation compared to stobadine $2 \mathrm{HCl}$. According to our previous investigations of these derivatives (Rapta et al. 2010), we concluded that both are far less effective in scavenging ${ }^{\circ} \mathrm{OH}$ and peroxy-type radicals compared to stobadine $\cdot 2 \mathrm{HCl}$.

The aim of the presented study was to investigate the antioxidative effects of two HHPI derivatives, namely SM1dM9dM10 $2 \mathrm{HCl}$ and SME1i-ProC2 $\cdot \mathrm{HCl}$, and compare those effects with that of stobadine $\cdot 2 \mathrm{HCl}$.

\section{Materials and Methods}

\section{Chemicals}

The high-molar-mass hyaluronan sample P9710-2A (weight average of molar masses $\mathrm{M}_{\mathrm{W}}=808.7 \mathrm{kDa}$; number average of molar masses $M_{n}=496.1 \mathrm{kDa}$; Šoltés et al. 2007b) was obtained from Lifecore Biomedical Inc. (Chaska, MN, U.S.A). The declared contents of transition metals in the HA sample were $4 \mathrm{ppm} \mathrm{Cu}$ and 13 ppm Fe.<smiles>CN1CCc2c(c3ccccc3n2Cc2ccccc2)C1</smiles><smiles>Cc1ccc2c(c1)C1CCN(C)CC1N2</smiles>

Mebhydroline
Carbidine<smiles>Cc1[nH]cnc1CN1CCc2[nH]c3ccccc3c2C1=O</smiles>

Alosterone

Figure 2. Structural scheme of pyridoindole derivatives. 
<smiles>COc1ccc2c(c1)[C@H]1CN(C(=O)OC(C)=O)CC[C@H]1N2</smiles>

\section{Stobadine $\cdot 2 \mathrm{HCl}$}

SM1dM9dM10 $2 \mathrm{HCl}$

\section{SME1i-ProC2 $\cdot \mathrm{HCl}$}

Figure 3. Structural scheme of pyridoindole - HHPI derivatives.

Analytical purity grade $\mathrm{NaCl}$ and $\mathrm{CuCl}_{2} \cdot 2 \mathrm{H}_{2} \mathrm{O}$ were purchased from Slavus Ltd. (Bratislava, Slovakia); L-ascorbic acid and potassium persulfate $\left(\mathrm{K}_{2} \mathrm{~S}_{2} \mathrm{O}_{8}\right.$; p.a. purity, $\max 0.001 \%$ nitrogen) were the products of Merck KGaA (Darmstadt, Germany); 2,2'-azinobis-(3-ethylbenzothiazoline-6-sulfonic acid (ABTS; purum, >99\%) was from Fluka (Steinheim, Germany). Stobadine. $2 \mathrm{HCl}$ and its two derivatives 2,2,3,3,8-pentametyl-2,3,4,4a,5,9bhexahydro- $1 H$-pyrido[4,3b]indolinium dihydrochlorid (SM1dM9dM10.2HCl) and 2-isopropyloxycarbonyl-8-methoxy-2,3,4,4a,5,9b-hexahydro- $1 H$-pyrido[4,3b]indolinium monohydrochloride $(\mathrm{SME} 1 \mathrm{i}-\mathrm{ProC} 2 \cdot \mathrm{HCl})$ were prepared at the Institute of Experimental Pharmacology and Toxicology (Bratislava, Slovakia) by the classical Fischer indole synthesis using 4-methylphenylhydrazine as a precursor (Štolc et al. 2010). Deionized high-purity grade water, with conductivity of $\leq 0.055 \mu \mathrm{S} / \mathrm{cm}$, was produced by using a water purification system of Thermo Scientific TKA (Niederelbert, Germany).

\section{ABTS assay}

The standard ABTS assay was applied as already reported (Re et al. 1999; Cheng et al. 2006). Briefly, the aqueous solution of $\mathrm{ABTS}^{\bullet+}$ cation radical was prepared $24 \mathrm{~h}$ before the measurement at room temperature as follows: ABTS aqueous stock solution $(7 \mathrm{mM})$ was mixed with $\mathrm{K}_{2} \mathrm{~S}_{2} \mathrm{O}_{8}$ aqueous solution $(2.45 \mathrm{mM})$ in equivolume ratio. The following day, $1.1 \mathrm{ml}$ of the resulting solution was diluted with $96 \%$ ethanol to the final volume of $50 \mathrm{ml}$. The ethanol-aqueous reagent of the volume $250 \mu \mathrm{l}$ was added to $2.5 \mu \mathrm{l}$ of the ethanolic solution of stobadine $2 \mathrm{HCl}$, SM1dM9dM10.2HCl or SME1i-ProC2 $\cdot \mathrm{HCl}$. The concentration range of tested substances was 101-0.808 $\mathrm{mM}$. Absorbance of the sample mixtures was recorded at 734 $\mathrm{nm}$ in the $6^{\text {th }}$ min after mixing the reactants.

The measurements were performed quadruplicately in 96-well Greiner UV-Star microplates (Greiner-Bio-One $\mathrm{GmbH}$, Germany) with Tecan Infinite M 200 reader (Tecan AG, Austria). The calculated values of $\mathrm{IC}_{50}$, expressed as mean \pm SEM, are absolute.
Solutions

The HA sample solutions were prepared in the dark at room temperature in $0.15 \mathrm{M}$ aqueous $\mathrm{NaCl}$ in two steps. First, 4.0 $\mathrm{ml}$ of the solvent was added to $20 \mathrm{mg} \mathrm{HA}$, and 3.90, 3.85, 3.70 or $3.40 \mathrm{ml}$ of the solvent was added after $6 \mathrm{~h}$. All stock solutions, including those of L-ascorbic acid (16 mM), stobadine. $2 \mathrm{HCl}$, and its two derivatives $(16 \mathrm{mM})$, cupric chloride ( $16 \mathrm{mM}$ diluted to a $16 \mu \mathrm{M}$ solution) were also prepared in $0.15 \mathrm{M}$ aqueous $\mathrm{NaCl}$.

\section{Hyaluronan oxidative degradation}

Oxidative degradation of HA was induced by the Weissberger system comprising L-ascorbic acid $(100 \mu \mathrm{M})$ and $\mathrm{CuCl}_{2}(0.1 \mu \mathrm{M})$. The procedure was as follows: a volume of $50 \mu \mathrm{l}$ of $\mathrm{CuCl}_{2}$ solution $(16 \mu \mathrm{M})$ was added to the HA solution $(7.90 \mathrm{ml})$ and the reaction mixture was left to stand for $7.5 \mathrm{~min}$ at room temperature after 30 -s stirring. Then, $50 \mu \mathrm{l}$ of $\mathrm{L}$-ascorbic acid solution ( $16 \mathrm{mM}$ ) were added to the HA solution and stirred again for $30 \mathrm{~s}$. The solution mixture was then immediately transferred into the viscometer teflon cup reservoir.

Procedures to investigate effects of stobadine $\cdot 2 \mathrm{HCl}$ and its two derivatives were as follows:

1) The solution of $\mathrm{CuCl}_{2}(16 \mu \mathrm{M})$ in the volume of $50 \mu \mathrm{l}$ was added to the HA solution $(7.85,7.70$ or $7.40 \mathrm{ml})$, which was left to stand for $7.5 \mathrm{~min}$ at room temperature after stirring for $30 \mathrm{~s}$. Then, 50, 200 or $500 \mu \mathrm{l}$ of the substance $(16 \mathrm{mM})$ were added to the solution and stirred again for $30 \mathrm{~s}$. Finally, $50 \mu \mathrm{l}$ of $\mathrm{L}$-ascorbic acid solution $(16 \mathrm{mM})$ were added to the HA solution and stirred for $30 \mathrm{~s}$. The solution mixture $(8.0 \mathrm{ml})$ was then immediately transferred into the viscometer teflon cup reservoir. By adding the substance in time $0 \mathrm{~min}$, i.e. before adding ascorbic acid, we investigated the capability of the tested substance to scavenge ${ }^{\circ} \mathrm{OH}$ radicals, i.e. to act as a preventive antioxidant (Šoltés et al. 2006).

2) In the second experimental setting a similar procedure as that described in (1) was applied, however, after leaving the 
reaction mixture for $7.5 \mathrm{~min}$ at room temperature, $50 \mu \mathrm{l}$ of L-ascorbic acid solution ( $16 \mathrm{mM}$ ) were added. After a 1-h stirring of the reaction mixture, finally 50,200 or $500 \mu \mathrm{l}$ of the substance solution $(16 \mathrm{mM})$ were added to the HA solution followed by 30 -s stirring. The reaction mixture ( 8.0 $\mathrm{ml}$ ) was then immediately transferred into the viscometer teflon cup reservoir. By adding the substance $1 \mathrm{~h}$ after admixing ascorbic acid, we investigated the capability of the tested substance to scavenge peroxy-type radicals, i.e. to act as a chain-breaking antioxidant (Valachová et al. 2010a).

\section{Rotational viscometry}

The resulting reaction mixture $(8.0 \mathrm{ml})$ was transferred into the teflon cup reservoir of a Brookfield LVDV-II+Pro digital rotational viscometer (Brookfield Engineering Labs., Inc., Middleboro, MA, USA). The recording of viscometer output parameters started $2 \mathrm{~min}$ after the experiment onset. The changes of the dynamic viscosity values of the reaction mixture were recorded at $25.0 \pm 0.1^{\circ} \mathrm{C}$ in 3 -min intervals for up to $5 \mathrm{~h}$. The viscometer teflon spindle rotated at $180 \mathrm{rpm}$, i.e. at a shear rate of $237.6 \mathrm{~s}^{-1}$.

\section{Results}

Table 1 presents the absolute $\mathrm{IC}_{50}$ values of the substances tested by the ABTS assay. As evident, the $\mathrm{IC}_{50}$ value of stobadine. $2 \mathrm{HCl}$ was found to be about 2- or 12-times lower compared to its derivatives SME1i-ProC2. $\mathrm{HCl}$ or SM1dM9dM10.2 HCl, respectively. This indicated that stobadine $\cdot 2 \mathrm{HCl}$ has the highest $\mathrm{ABTS}^{\bullet+}$ cation radical scavenging capacity among the compounds tested.

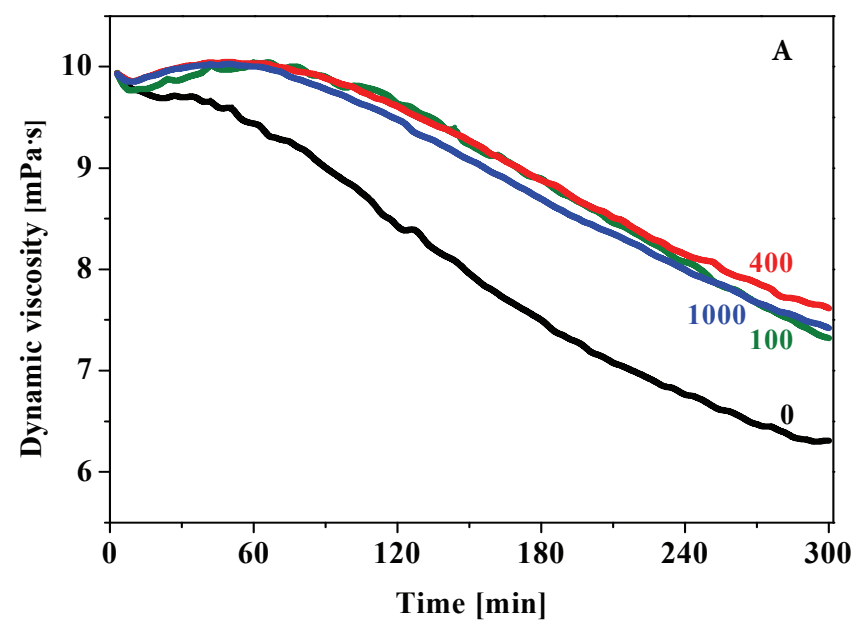

Table 1. The absolute $\mathrm{IC}_{50}$ values of stobadine. $2 \mathrm{HCl}$ and its two derivatives determined by the ABTS assay

\begin{tabular}{ll}
\hline Substance & $\mathrm{IC}_{50}(\mu \mathrm{M})$ \\
\hline Stobadine·2HCl & $12.6 \pm 0.24$ \\
SME1i-ProC2·HCl & $27.6 \pm 0.46$ \\
SM1dM9dM10·2HCl & $155 \pm 2.2$ \\
\hline
\end{tabular}

Values are means $\pm \operatorname{SEM}(n=4)$.

Figure 4 shows typical recordings of free-radical-mediated degradation of the high-molar-mass HA by the oxidative system ascorbate plus $\mathrm{Cu}$ (II) monitored by rotational viscometry (curves 0 ). Addition of stobadine $2 \mathrm{HCl}$ to the reaction mixture (time $=0 \mathrm{~min}$ ) led to a dose-independent $(100,400,1000 \mu \mathrm{M})$ total inhibition of HA degradation initiated by ${ }^{\circ} \mathrm{OH}$ radicals up to approx. $60 \mathrm{~min}$. Then, a gradual decrease of HA dynamic viscosity was observed (Fig. 4A, curves $100,400,1000)$. When applying stobadine $\cdot 2 \mathrm{HCl}$ to the reaction mixture after $1 \mathrm{~h}$, it was shown to be an effective scavenger of peroxy-type free radicals. This fact was observed again up to approx. $60 \mathrm{~min}$ from the measurement onset. Then, however, a dose-independent gradual decrease of $\mathrm{HA}$ dynamic viscosity was recorded for stobadine $\cdot 2 \mathrm{HCl}$ tested at lower concentrations (Fig. 4B, curves 100, 400). At the highest concentration (Fig. 4B, curve 1000) it exerted a somewhat more pronounced protection against the peroxy-radical-mediated HA degradation.

The results of SM1dM9dM10.2 HCl action are depicted in Figure 5. At the lower concentrations applied (100 and $400 \mu \mathrm{M})$ the compound exhibited a significant protective effect against the ${ }^{\circ} \mathrm{OH}$ radical-induced degradation of HA for approx. 90 and 60 min, respectively. Further, a moder-

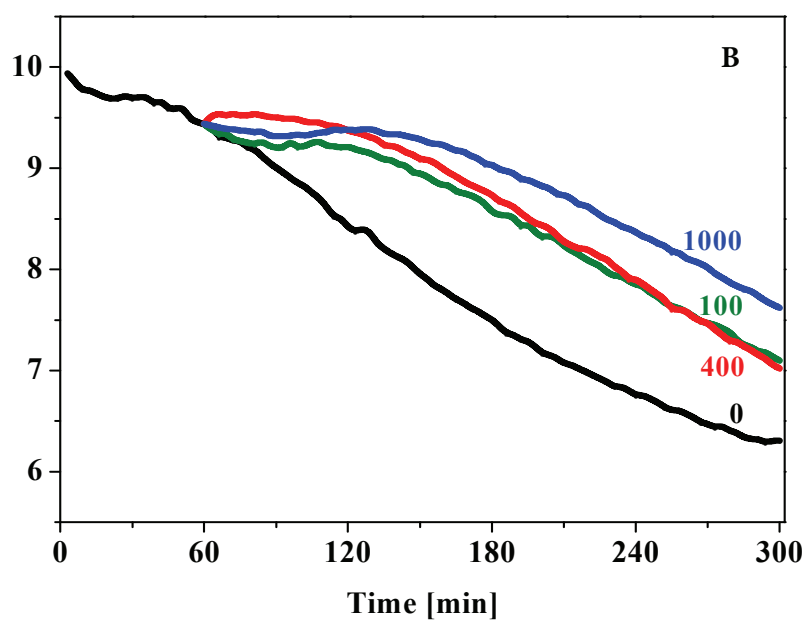

Figure 4. Effect of stobadine $2 \mathrm{HCl}$ on $\mathrm{HA}$ degradation induced by the oxidative system containing $0.1 \mu \mathrm{M} \mathrm{CuCl}_{2}+100 \mu \mathrm{M}$ ascorbic acid. Stobadine. $2 \mathrm{HCl}(0,100,400$, and $1000 \mu \mathrm{M})$ added in the oxidative system before the start $(\mathbf{A})$ or after $1 \mathrm{~h}(\mathbf{B})$ of HA degradation. Concentration of the HA solution was $2.5 \mathrm{mg} / \mathrm{ml}$. 

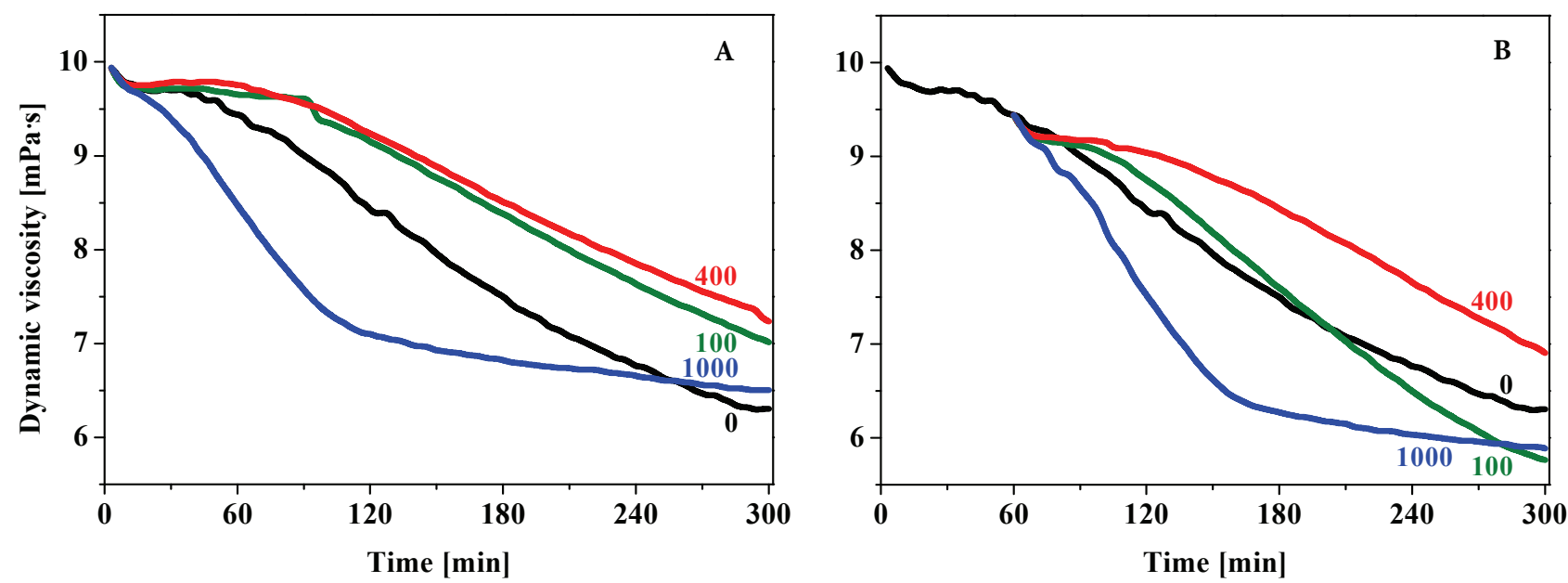

Figure 5. Effect of SM1dM9dM10.2 $\mathrm{HCl}$ on $\mathrm{HA}$ degradation induced by the oxidative system containing $0.1 \mu \mathrm{M} \mathrm{CuCl} 2+100 \mu \mathrm{M}$ ascorbic acid. SM1dM9dM10.2 $\mathrm{HCl}(0,100,400$, and $1000 \mu \mathrm{M})$ added in the oxidative system before the start (A) or after $1 \mathrm{~h}(\mathbf{B})$ of $\mathrm{HA}$ degradation. Concentration of the HA solution was $2.5 \mathrm{mg} / \mathrm{ml}$.

ately increased rate of HA degradation was monitored at both substance concentrations (Fig. 5A, curves 100, 400). However, further increase of the concentration $(1000 \mu \mathrm{M})$ resulted in a rapid decrease of HA dynamic viscosity for approx. $120 \mathrm{~min}$, followed by a decreased rate of HA degradation (Fig. 5A, curve 1000). Testing the substance as a scavenger of peroxy radicals showed dose-dependence, i.e. at the concentration of $400 \mu \mathrm{M}$ SM1dM9dM10.2HCl exerted a moderate scavenging activity. On the other hand, increasing its concentration up to $1000 \mu \mathrm{M}$ led to a significant decrease of HA dynamic viscosity values (Fig. 5B, curve 1000).

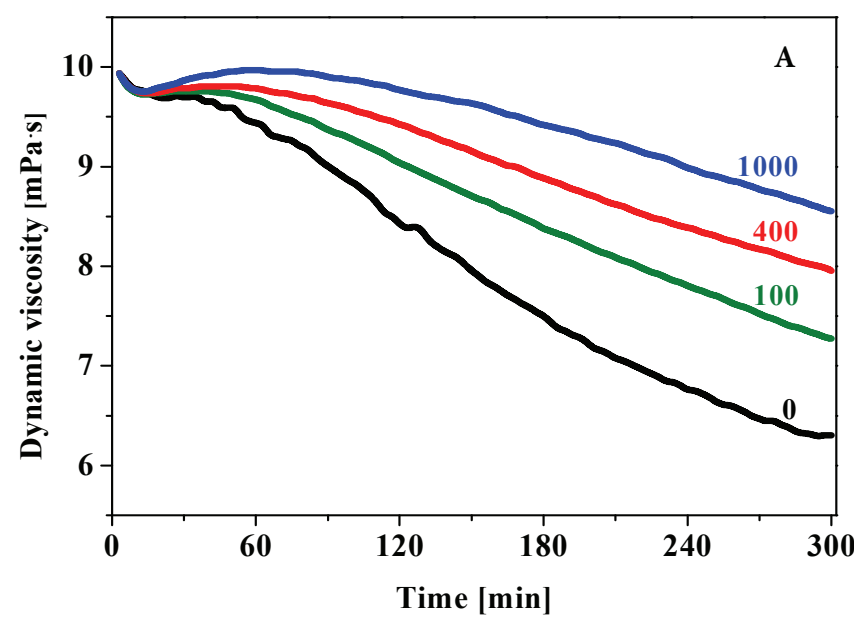

Figure 6 displays the results of adding SME1i-ProC2 $\cdot \mathrm{HCl}$ to the above mentioned reaction mixture inducing HA degradation. SME1i-ProC2. $\mathrm{HCl}$ exerted total inhibitory activity of HA degradation for a certain period of time (approx. $60 \mathrm{~min}$ ). Then the dynamic viscosity of HA decreased moderately in a dose-dependent manner (Fig. 6A, curves $100,400,1000)$. However, practically no inhibitory effect against peroxy-type radicals was observed at the lowest concentration of the SME1i-ProC2.HCl (Fig. 6B, curve 100) compared to the reference (curve 0 ). On the other hand, a partial protective effect against radical-induced HA degradation was found for the substance at the higher

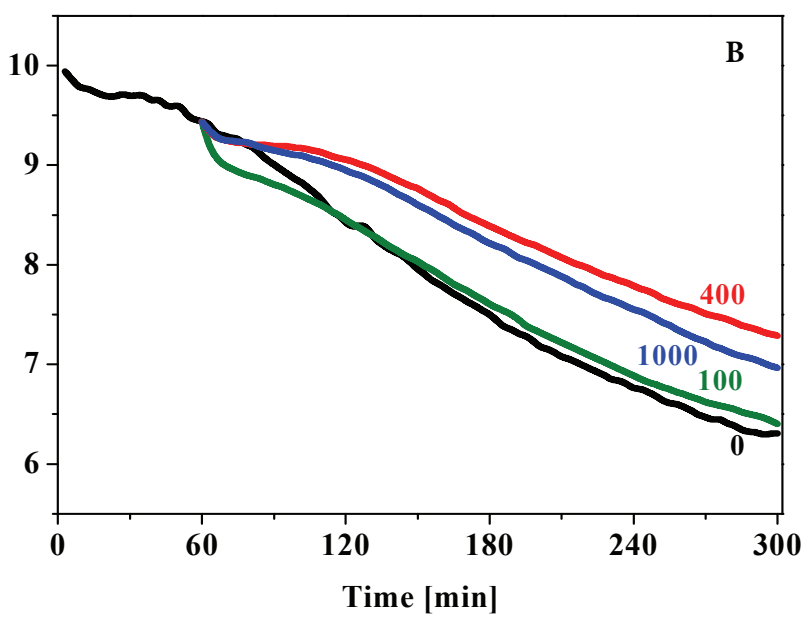

Figure 6. Effect of SME1i-ProC2 $\cdot \mathrm{HCl}$ on $\mathrm{HA}$ degradation induced by the oxidative system containing $0.1 \mu \mathrm{M} \mathrm{CuCl}_{2}+100 \mu \mathrm{M}$ ascorbic acid. SME1i-ProC2 $\cdot \mathrm{HCl}(0,100,400$, and $1000 \mu \mathrm{M})$ added into the system before the start (A) or after $1 \mathrm{~h}(\mathbf{B})$ of HA degradation. Concentration of the HA solution was $2.5 \mathrm{mg} / \mathrm{ml}$. 
concentrations, i.e. 400 and $1000 \mu \mathrm{M}$ (Fig. 6B, curves 400, 1000).

\section{Discussion}

The hexahydropyridoindole stobadine $\cdot 2 \mathrm{HCl}$ was observed to be by far the most effective scavenger of $\mathrm{ABTS}^{\bullet+}$ cation radical in comparison to the other substances tested. The absolute $\mathrm{IC}_{50}$ value of stobadine $2 \mathrm{HCl}$ equaled to $12.6 \mu \mathrm{M}$ is relatively low, however, other substances tested such as $\mathrm{D}$-penicillamine, arbutin or bucillamine were found to have even lower $\mathrm{IC}_{50}$ values: $5.26,5.40$ or $4.00 \mu \mathrm{M}$, respectively. Quercetin may be considered a standard ABTS ${ }^{\bullet+}$ radical cation scavenger. Its absolute $\mathrm{IC}_{50}$ value represents $2.86 \mu \mathrm{M}$. On the other hand, the absolute $\mathrm{IC}_{50}$ value of SM1dM9dM10.2 $\mathrm{HCl}$ was determined to be relatively high $(155 \mu \mathrm{M})$. When examining L-cysteine, its $\mathrm{IC}_{50}$ represented the value $\sim 1300 \mu \mathrm{M}$, which was more than 8 -times higher compared to SM1dM9dM10.2HCl. For other substances such as L-glutathione and cysteamine the $\mathrm{IC}_{50}$ values were 24.0 and $179 \mu \mathrm{M}$, respectively (Valachová et al. 2010a).

The ABTS spectrophotometric assay is technically simple, which accounts for its application for screening and routine determinations. However, results obtained for the sample of interest have to be normalized since different compounds may exert different kinetic behavior. Moreover, this assay has been criticized as the $\mathrm{ABTS}^{\bullet+}$ cation radical is not a representative of biomolecules and is not even found in any biological system. Thermodynamically, any compound that has redox potential lower than that of $\mathrm{ABTS}^{\bullet+}$ cation radical may react with it (Magalhaes et al. 2008).

In the present study, the ABTS assay has been applied for the first time for HHPI substrates, yet antioxidative properties of stobadine. $2 \mathrm{HCl}$ had been already investigated. The abilities of stobadine to effectively eliminate ${ }^{\bullet} \mathrm{OH}$, alkoxy-, peroxy- radicals and to quench singlet oxygen have already been published (Ondriáš et al. 1989; Štefek and Beneš 1991; Štefek et al. 1992; Steenken et al. 1992; Kagan et al. 1993; Horáková et al. 1995, 1996; Štefek and Trnková 1996; Juránek et al. 2010). However, in the function of a scavenger of free-radicals generated by the Weissberger oxidative system stobadine $\cdot 2 \mathrm{HCl}$ has been investigated already in detail by Rapta et al. (2010) for the first time. The oxidative system imitates the conditions occurring in an early stage of acute joint inflammation. Besides stobadine $2 \mathrm{HCl}$, two stobadine derivatives $\mathrm{SMe} 1 \mathrm{EC} 2 \cdot \mathrm{HCl}$ and $\mathrm{SM} 1 \mathrm{M} 3 \mathrm{EC} 2 \cdot \mathrm{HCl}$ were also tested. This is the first time these two derivatives have been tested by applying rotational viscometry and ABTS assay.

The study was focused on the comparison of stobadine $2 \mathrm{HCl}$ derivatives, namely $\mathrm{SM} 1 \mathrm{dM} 9 \mathrm{dM} 10 \cdot 2 \mathrm{HCl}$ and SME1i-ProC2.HCl, considering the following facts: by examing stobadine. $2 \mathrm{HCl}$ and $\mathrm{SM} 1 \mathrm{dM} 9 \mathrm{dM} 10 \cdot 2 \mathrm{HCl}$ thor- oughly, theoretically the higher antioxidative activity of SM1dM9dM10.2 $\mathrm{HCl}$ compared to stobadine $\cdot 2 \mathrm{HCl}$ may be assumed, based on the presence of two reactive centers in the SM1dM9dM10.2 HCl molecule in the positions 2- and 5-. Stobadine. $2 \mathrm{HCl}$ has $\alpha$-adrenolytic, negative chronotropic and inotropic properties which account for its hypotensive effect. The ability of stobadine $2 \mathrm{HCl}$ to decrease blood pressure can be adverse, especially when administered in acute states (heart attack, sudden cerebral episodes, acute traumas of head and spinal cord, etc.). The administration of substance SM1dM9dM10.2 $\mathrm{HCl}$ has several advantages. Besides the above mentioned positive effect, the substance SM1dM9dM10.2HCl has no a-adrenolytic effect (Štolc et al. 2010).

In spite of expecting a high efficacy of substance SM1dM9dM10.2HCl, its antioxidative activity, examined by the ABTS assay, was found to be significantly lower compared to stobadine. $2 \mathrm{HCl}$ and substance SME1i-ProC2 $\cdot \mathrm{HCl}$. The results obtained by the method of rotational viscometry indicated that the preventive effect of substance SM1dM9dM10.2 HCl was comparable to that of stobadine. $2 \mathrm{HCl}$. However, when applying substance SM1dM9dM10.2 HCl at the highest concentration, a rapid pro-oxidative effect was recorded. As resulted from the ABTS assays, the antioxidative efficacy of the derivative SME1i-ProC2. $\mathrm{HCl}$ was found to be comparable to that of stobadine $2 \mathrm{HCl}$. The absolute $\mathrm{IC}_{50}$ value of SME1i-ProC2 $\cdot \mathrm{HCl}$ was approximately $47 \%$ compared to stobadine $2 \mathrm{HCl}$.

The results of studying HA degradation indicate that SME1i-ProC2 $\cdot \mathrm{HCl}$ possesses a significant preventive antioxidative property, reflected by the inhibition of HA oxidative degradation, and at the highest concentration of $1000 \mu \mathrm{M}$, it completely inhibited HA degradation up to approx. $90 \mathrm{~min}$. The results of rotational viscometry showed that the substances added $1 \mathrm{~h}$ after the initiation of HA degradation were effective chain-breaking antioxidants in the order stobadine, derivatives SM1dM9dM10.2 HCl, and finally SME1i-ProC2.HCl. Despite our expectations, the inhibitory effect of the substances stobadine $2 \mathrm{HCl}$, SM1dM9dM10.2HCl, SME1i-ProC2 $\cdot \mathrm{HCl}$ on HA degradation lasted only for a certain period, and was followed by a propagation phase, whose rate was similar to that recorded in the absence of the substances. The only exception was substance SME1i-ProC2. $\mathrm{HCl}$ at its higher concentrations $(400,1000 \mu \mathrm{M})$, which led to retardation of free radical HA degradation. Unlike some well established antiinflammatory drugs, aurothiomalate and bucillamine were capable to totally inhibit free-radical-induced high-molar-mass HA degradation before or after initiating HA degradation at significantly lower concentrations, i.e. 50 and $10 \mu \mathrm{M}$, respectively. Such a remarkable protective effect of bucillamine could be partly related to its chelation with copper ions (Valachová et al. 2011). 
From the methological point of view, it could be stated that ABTS assay can be used in screening proper substances, yet it is desirable to carry out further screening of antioxidative activity under conditions which imitate pathophysiological conditions. One of the approaches may be rotational viscometry, which was worked out in our laboratory and has been used ever since (Orviský et al. 1994). This method was applied in testing antioxidative efficacy of substances such as naproxen, acetylsalicilic acid, melatonin, L-glutathione, D-penicillamine, Mn(II) (Šoltés et al. 2007b; Rapta et al. 2009; Valachová et al. 2009a,b; Hrabárová et al. 2010, Stankovská and Šoltés 2010; Valachová et al. 2010a,b,c). We are confident that it has a potential to be used more broadly in testing prospective compounds with antioxidative properties, which were demonstrated in the case of pyridoindoles, namely stobadine.2HCl (Juránek et al. 2010). Although, both tested hydrophilic stobadine derivatives - SM1dM9dM10 $2 \mathrm{HCl}$ and SME1i-ProC2.HCl - are represented with diminished $\alpha$-adrenolytic effect, their free-radical scavenging properties did not reach that of stobadine $2 \mathrm{HCl}$.

Acknowledgement: VEGA 2/0011/11, 2/0083/09, 2/0081/11. This paper is the result of the project implementation ITMS26240220040 supported by the Research \& Development Operational Programme funded by the ERDF. The authors thank to Dr. Štefan Bezek for his critical reading of the manuscript.

\section{References}

Cheng Z., Moore J., Yu L. (2006): High-throughput relative DPPH radical scavenging capacity assay. J. Agric. Food Chem. 54, $7429-7436$

http://dx.doi.org/10.1021/jf0611668

Horáková L., Schaur R. J., Balgavý P., Egger G. (1995): Interaction of the pyridoindole stobadine with alkoxyl and stable free radicals. Redox Rep. 1, 369-372

Horáková L., Schaur R. J., Balgavý P. (1996): The crocin assay for the determination of relative rate constants of alkoxyl radical reactions with the pyridoindole stobadine and with other antioxidants. Redox Rep. 2, 401-405

Hrabárová E., Valachová K., Rapta P., Šoltés L. (2010): An alternative standard for Trolox-equivalent antioxidant-capacity estimation based on thiol antioxidants. Comparative 2,2' -azinobis[3-ethylbenzothiazoline-6-sulfonic acid] decolorization and rotational viscometry study regarding hyaluronan degradation. Chem. Biodivers. 7, 2191-2200

Hung D. (2008): Hydrogenated pyrido [4,3-b] indoles such as Dimebon for treating canine cognitive dysfunction syndrome. US Patent No. 2007/020483

Ivachtchenko A. V., Mitkin O. D., Kadieva M. G., Tkachenko S. E. (2010): The synthesis and physiological activity of 2,3,4,5-tetrahydro-1H-pyrido[4,3-b]indoles. Rus. Chem. Rev. 79, 285-306 http://dx.doi.org/10.1070/RC2010v079n04ABEH004122

Ivashchenko A. A., Ivachtchenko A. V., Tkachenko S. Y., Frolov E. B., Mitkin O. D., Kravchenko D. V., Okun I. M., Savchuk
N. F., Lavrovsky Y. (2010): Substituted 2,3,4,5-tetrahydro-1H-pyrido[4,3-b] indoles, methods for the production and use thereof. EP2145887A2

Juránek I., Horáková L., Račková L., Štefek M. (2010): Antioxidants in treating pathologies involving oxidative damage: An update on medicinal chemistry and biological activity of stobadine and related pyridoindoles. Curr. Med. Chem. 17, 552-570 http://dx.doi.org/10.2174/092986710790416317

Kagan V. E., Tsuchiya M., Serbinova E., Packer L., Sies H. (1993): Interaction of the pyridoindole stobadine with peroxyl, superoxide and chromanoxyl radicals. Biochem. Pharmacol. 45, 393-400 http://dx.doi.org/10.1016/0006-2952(93)90075-8

Kittová M., Gibala P., Dřímal J. (1985): Antiarrhythmic and hemodynamic effects of derivatives of pyridoindole (DH 1011) on experimental models of disorders of rhythm and heart function. Bratisl. Lek. Listy 84, 542-549 (in Slovak)

Kogan G., Šoltés L., Stern R., Gemeiner P. (2007): Hyaluronic acid: A natural biopolymer with a broad range of biomedical and industrial applications. Biotechnol. Lett. 29, 17-25 http://dx.doi.org/10.1007/s10529-006-9219-z

Kongtawelert P., Ghosh P. (1989): An enzyme-linked immunosorbent-inhibition assay for quantitation of hyaluronan (hyaluronic acid) in biological fluids. Anal. Biochem. 178, 367-372 http://dx.doi.org/10.1016/0003-2697(89)90654-4

Magalhaes L. M., Segundo M. A., Reis S., Lima J. L. F. C. (2008): Methodological aspects about in vitro evaluation of antioxidant properties. Anal. Chim. Acta 613, 1-19 http://dx.doi.org/10.1016/j.aca.2008.02.047

Ondriáš K., Miš́k V., Gergel` D., Staško A. (1989): Lipid peroxidation of phosphatidylcholine liposomes depressed by the calcium channel blockers nifedipine and verapamiI and by the antiarrhythmic-antihypoxic drug stobadine. Biochim. Biophys. Acta 1003, 238-245

Orviský E., Šoltés L., Stančíková M., Vyletelová Z., Juránek I. (1994): Assessment of antioxidative properties of hydrophilic xenobiotics on the basis of inhibition of the radical degradation of hyaluronan by reactive oxygen species. CS Patent No. 2764 (in Slovak)

Puré E., Assoian R. K. (2009): Rheostatic signaling by CD44 and hyaluronan. Cell. Signal. 21, 651-655 http://dx.doi.org/10.1016/j.cellsig.2009.01.024

Račková L., Štefek M., Májeková M. (2002): Structural aspects of antioxidant activity of substituted pyridoindoles. Redox Rep. $7,207-214$ http://dx.doi.org/10.1179/135100002125000578

Rapta P., Valachová K., Gemeiner P., Šoltés L. (2009): High-molar-mass hyaluronan behavior during testing its radical scavenging capacity in organic and aqueous media: Effects of the presence of manganese(II) ions. Chem. Biodivers. 6, 162-169 http://dx.doi.org/10.1002/cbdv.200800075

Rapta P., Valachová K., Zalibera M., Šnirc V., Šoltés L. (2010): Hyaluronan degradation by reactive oxygen species. Scavenging effect of the hexahydropyridoindole stobadine and two of its derivatives. In: Monomers, Oligomers, Polymers, Composites and Nanocomposites Research: Synthesis, Properties and Applications. (Eds. R. A. Pethrick, P. Petkov, A. Zlatarov, G. E. Zaikov and S. K. Rakovsky), pp. 113-126, Nova Science Publishers, New York

Re R., Pellegrini N., Proteggente A., Pannala A., Yang M., Rice-Evans C. (1999): Antioxidant activity applying an improved 
ABTS radical cation decolorization assay. Free Radic. Biol. Med. 26, 1231-1237

http://dx.doi.org/10.1016/S0891-5849(98)00315-3

Schoenfeld P. (2005): Efficacy of current drug therapies in irritable bowel syndrome: What works and does not work. Clin. North. Am. 34, 319-335

Stankovská M., Šoltés L. (2010): Oxidative degradation of hyaluronan: Is melatonin an antioxidant or prooxidant. In: Monomers, Oligomers, Polymers, Composites and Nanocomposites Research: Synthesis, Properties and Applications. (Eds. R. A. Pethrick, P. Petkov, A. Zlatarov, G. E. Zaikov and S. K. Rakovsky), pp. 59-67, Nova Science Publishers, New York

Staško A., Ondriáš K., Mišík V. (1990): Stobadine - a novel scavenger of free radicals. Chem. Pap. 44, 493-500

Steenken S., Sundquist A. R., Jovanovic S. V., Crockett R., Sies H. (1992): Antioxidant activity of the pyridoindole stobadine. Pulse radiolytic characterization of one-electron-oxidized stobadine and quenching of singlet molecular oxygen. Chem. Res. Toxicol. 5, 355-360 http://dx.doi.org/10.1021/tx00027a006

Stern R. (2003): Devising a pathway for hyaluronan catabolism: Are we there yet? Glycobiology 13, 105-115 http://dx.doi.org/10.1093/glycob/cwg112

Stern R., Kogan G., Jedrzejas M. J., Šoltés L. (2007): The many ways to cleave hyaluronan. Biotechnol. Adv. 25, 537-557 http://dx.doi.org/10.1016/j.biotechadv.2007.07.001

Šoltés L., Bezek Š., Ujházy E., Bauer V. (2000): Extraction and chromatographic separation methods in pharmacokinetic studies of Stobadine - an indole-related antioxidant and free-radical scavenger. Biomed. Chromatogr. 14, 188-201

Šoltés L., Stankovská M., Kogan G., Gemeiner P., Stern R. (2005): Contribution of oxidative-reductive reactions to high-molecular-weight hyaluronan catabolism. Chem. Biodivers. 2, 1242-1245 http://dx.doi.org/10.1002/cbdv.200590094

Šoltés L., Stankovská M., Brezová V., Schiller J., Arnhold J., Kogan G., Gemeiner P. (2006): Hyaluronan degradation by copper(II) chloride and ascorbate: Rotational viscometric, EPR spin-trapping, and MALDI-TOF mass spectrometric investigations. Carbohydr. Res. 341, 2826-2834

Šoltés L. Stankovská M., Kogan G., Mendichi R., Volpi N., Sasinková V., Gemeiner P. (2007a): Degradation of high-molar-mass hyaluronan by an oxidative system comprising ascorbate, $\mathrm{Cu}(\mathrm{II})$, and hydrogen peroxide: Inhibitory action of antiinflammatory drugs - Naproxen and acetylsalicylic acid. J. Pharm. Biomed. Anal. 44, 1056-1063

Šoltés L., Valachová K., Mendichi R., Kogan G., Arnhold J., Gemeiner P. (2007b): Solution properties of high-molar-mass hyaluronans: The biopolymer degradation by ascorbate. Carbohyd. Res. 342, 1071-1077

http://dx.doi.org/10.1016/j.carres.2007.02.018

Štefek M., Beneš L. (1991): Pyridoindole stobadine is a potent scavenger of hydroxyl radicals. FEBS Lett. 294, 264-266 http://dx.doi.org/10.1016/0014-5793(91)81444-D

Štefek M., Masaryková M., Beneš L. (1992): Inhibition of cumene hydroperoxide induced lipid peroxidation by a novel pyridoindole antioxidant in rat liver microsomes. Pharmacol. Toxicol. 70, 407-411 http://dx.doi.org/10.1111/j.1600-0773.1992.tb00498.x

Štefek M., Trnková Z. (1996): The pyridoindole antioxidant stobadine prevents alloxan-induced lipid peroxidation by inhibiting its propagation. Pharmacol. Toxicol. 78, 77-81 http://dx.doi.org/10.1111/j.1600-0773.1996.tb00183.x

Štolc S., Považanec F., Bauer V., Májeková M., Wilcox A. L., Šnirc V., Račková L., Sotníková R., Štefek M., Gáspárová Z., Gajdošíková A., Mihálová D., Alfoldi J. (2010): Pyridoindole derivatives with antioxidant properties: Their synthesis and use in therapeutic practice. SK Patent No. 287506 (in Slovak)

Valachová K., Rapta P., Kogan G., Hrabárová E., Gemeiner P., Šoltés L. (2009a): Degradation of high-molar-mass hyaluronan by ascorbate plus cupric ions: Effects of D-penicillamine addition. Chem. Biodivers. 6, 389-395 http://dx.doi.org/10.1002/cbdv.200800261

Valachová K., Kogan G., Gemeiner P., Šoltés L. (2009b): Hyaluronan degradation by ascorbate: Protective effects of manganese(II) chloride. In: Kinetics \& Thermodynamics for Chemistry \& Biochemistry. (Eds. E. M. Pearce, G. E. Zaikov and G. Kirshenbaum), pp. 201-215, Nova Science Publishers, New York

Valachová K., Hrabárová E., Dráfi F., Juránek I., Bauerová K., Priesolová E., Nagy M., Šoltés L. (2010a): Ascorbate and Cu(II)-induced oxidative degradation of high-molar-mass hyaluronan. Pro- and antioxidative effects of some thiols. Neuroendocrinol. Lett. 31 (Suppl. 2), 101-104

Valachová K., Kogan G., Gemeiner P., Šoltés L. (2010b): Protective effects of manganese(II) chloride on hyaluronan degradation by oxidative system ascorbate plus cupric chloride. Interdisc. Toxicol. 3, 26-34 http://dx.doi.org/10.2478/v10102-010-0001-7

Valachová K., Mendichi R., Šoltés L. (2010c): Effect of L-glutathione on high-molar-mass hyaluronan degradation by oxidative system Cu(II) plus ascorbate. In: Monomers, Oligomers, Polymers, Composites, and Nanocomposites. (Eds. R. A. Pethrick, P. Petkov, A. Zlatarov, G. E. Zaikov and S. K. Rakovsky), pp. 101-111, Nova Science Publishers, New York

Valachová K., Hrabárová E., Priesolová E., Nagy M., Baňasová M., Juránek I., Šoltés L. (2011): Free-radical degradation of high-molecular-weight hyaluronan induced by ascorbate plus cupric ions. Testing of bucillamine and its SA981-metabolite as antioxidants. J. Pharm. Biomed. Anal. 56, 664-670 http://dx.doi.org/10.1016/j.jpba.2011.06.015

Waitzinger J., Lenders H., Pabst G., Ulbrich E. (1995): Three explorative studies on the efficacy of the antihistamine mebhydroline (Omeril). Int. J. Clin. Pharmacol. Ther. 33, 373-383

Yakhontov L. N., Glushkov R. G. (1983). Synthetic Drugs. (Ed. A. G. Natradze), pp. 234-237, Meditsina Publishing House, Moscow (in Russian)

Yamazaki K., Fukuda K., Matsukawa M., Hara F., Yoshida K., Akagi M., Munakata H., Hamanishi C. (2003): Reactive oxygen species depolymerize hyaluronan: Involvement of the hydroxyl radical. Pathophysiology 9, 215-220

http://dx.doi.org/10.1016/S0928-4680(03)00024-5

Received: July 7, 2011

Final version accepted: November 21, 2011 